\title{
Altered Ratios of Beta-Endorphin : Beta-Lipotropin Released from Anterior Lobe Corticotropes with Increased Secretory Drive. I. Effects of Diminished Glucocorticoid Secretion
}

\author{
Elizabeth A. Young, Ryszard Przewlocki, Paresh Patel, Stanley J. Watson and Huda Aki! \\ Mental Health Research Institute, Department of Psychiatry, University of Michigan, 205 Zina Pitcher Place, Ann Arbor, Michigan 48109. \\ USA.
}

Key words: peptide processing, opioid peptides, adrenalectomy, metyrapone.

\begin{abstract}
Previous studies have demonstrated that acute stress or ovine corticotropin-releasing hormone (oCRH) in vivo, or oCRH in vitro, stimulates release of $\beta$-endorphin over $\beta$-lipotropin from anterior pituitary corticotropes. This occurs despite the predominance of $\beta$-lipotropin in corticotrope peptide stores. In vitro studies with primary anterior pituitary cultures suggested that chronic exposure to $\mathrm{OCRH}$ results in a shift towards more $\beta$-lipotropin secretion into the media than with short-term exposure. The current studies explored whether increased secretory drive in vivo results in a similar shift towards more $\beta$-lipotropin. We used removal of glucocorticoids by adrenalectomy or metyrapone blockade of corticosterone synthesis, to stimulate endogenous secretion of $\mathrm{CRH}$ and vasopressin. Both treatments resulted in shifts of the ratio of $\beta$-endorphin : $\beta$-lipotropin in plasma of experimental animals in comparison to the sham-treated control rats. In vitro testing with oCRH of anterior lobe cultures from adrenalectomized or metyrapone-treated rats demonstrated similar effects of these treatments on the ratio of $\beta$-endorphin: $\beta$-lipotropin. These changes occurred despite similar ratios of $\beta$-endorphin : $\beta$-lipotropin in anterior pituitary peptide stores.
\end{abstract}

Adrenocorticotropin (ACTH) and $\beta$-endorphin are synthesized as part of a larger precursor molecule known as proopiomelanocortin (POMC). The anterior pituitary corticotrope processes the C-terminal region of POMC to ACTH ${ }_{1-39}$ and either $\beta$ lipotropin $(\beta$-LPH) or $\beta$-endorphin, with $\beta$-LPH predominating over $\beta$-endorphin as the end product of processing by 2 - to 3 -fold $(1,2)$. Despite the predominance of $\beta$-LPH over $\beta$ endorphin in the total stores of anterior pituitary corticotropes, we have demonstrated that acute stress or ovine corticotropinreleasing hormone $(\mathrm{oCRH})$ in vitro leads to the preferential release of $\beta$-endorphin over $\beta$-LPH from anterior lobe corticotrope in rats (3). A similar preferential release of $\beta$-endorphin over $\beta$-LPH was demonstrated in man following oCRH infusion or electrically-induced seizures, suggesting that $\beta$-endorphin predominates over $\beta$-LPH in the releasable pools of corticotropes $(4,5)$. However, the effects of chronic exposure to $\mathrm{CRH}$ on the ratio of $\beta$-endorphin to $\beta$-LPH in the corticotrope's releasable pools is less clear. Chronic CRH exposure of anterior pituitary primary cell cultures has been shown to have a number of biosynthetic effects which could impact upon releasable pools in the corticotrope. For example, continuous $\mathrm{CRH}$ exposure in vitro leads to an increase in ACTH and $\beta$-endorphin $/ \beta$-LPH released into the media over time as well as an increase in biosynthesis (6-8). The study of Wand et al. (8) using primary anterior pituitary cultures suggested that chronic CRH administration to these cultures leads to a proportionately greater release of $\beta$-LPH over $\beta$-endorphin in the media. Likewise, studies by Ham and Smyth $(9,10)$ also demonstrated changes in anterior corticotrope processing and secretion following in vitro cxposure to oCRH. In vivo, the effects of chronic CRH administration on processing and forms secreted have not been explored. Since the stimulatory effects of $\mathrm{CRH}$ are balanced by the inhibitory effects of glucocorticoids on both corticotrope secretion and POMC biosynthesis in vivo, removal of the inhibitory effects of glucocorticoids by adrenalectomy (ADX) can serve as a means of increasing endogenous $\mathrm{CRH}$ release and consequently driving corticotrope secretion $(6,11-13)$.

Following ADX there is a rapid increase in plasma $\mathrm{ACTH}$ and $\beta$-endorphin immunoreactivity (IR). This leads to a depletion of anterior lobe ACTH content by 1 day (13). This depletion is accompanied by an increase in mRNA for POMC leading to an increase in POMC biosynthesis. After several days the corticotrope ACTH content returns to normal, despite continued increased secretion of $\mathrm{ACTH}$ and $\beta$-endorphin into plasma. In view of the absence of negative feedback of glucocorticoids on release, this increased activation continues to drive transcription 
of POMC mRNA and POMC biosynthesis leading to an increased content and increased levels of POMC mRNA, similar to the situation with chronic $\mathrm{CRH}$ administration in vitro. This greatly increased secretory drive could impact upon the processing of $\beta$-LPH to $\beta$-endorphin.

In vivo more than one secretagog elicits corticotrope secretion. The removal of glucocorticoid negative feedback affects both CRH and arginine vasopressin (AVP) secretion and results in expression of AVP in CRH neurons and release of AVP into the hypophyseal portal blood (14). This induction of AVP can be seen following both $\mathrm{ADX}$ and treatment with metyrapone, an $11 \beta$-hydroxylase inhibitor of corticosterone synthesis (15). Thus, following glucocorticoid removal the anterior pituitary is exposed to both increased CRH and AVP in a continuous rather than the usual pulsatile, circadian fashion. This sustained exposure to $\mathrm{CRH}$ and AVP may have different consequences than $\mathrm{CRH}$ in vitro. To evaluate the effects of increased secretory drive on the secretion of $\beta$-endorphin and $\beta$-LPH in vivo we utilized the removal of glucocorticoid negative feedback by either ADX or treatment with metyrapone as a stimulus to corticotrope secretion and biosynthesis.

\section{Results}

\section{Plasma data}

ADX is followed by release of $\beta$-endorphin-IR into plasmia. A time course of plasma values is shown in Fig. 1. Each time point represents a mean of 3 sham and 5 to 6 ADX animals. As can be seen there is no difference between sham ADX and ADX animals at the $12 \mathrm{~h}$ time point. The low concentrations of $\beta$ endorphin-IR in plasma of these $12 \mathrm{~h}$ ADX may be secondary to the tremendous decrease in anterior pituitary $\beta$-endorphin-IR content (14\% of sham ADX; Fig. 1B). By 3 days, there is an increase in plasma concentrations which persists to the final time point, 10 days $\mathrm{ADX}$.
To determine the ratio of $\beta-L \mathrm{PH}$ to $\beta$-endorphin present in plasma, the plasma from 5 to 6 ADX animals for each ADX time point was pooled and applied to a G-50 molecular sieving column. The plasma from two groups of shams ( 6 animals) was pooled to generate sham profiles. The sieving profiles from each pool of sham were similar, showing a very small amount of $\beta$ LPH size and a large peak of $\beta$-endorphin size material (ratio of $\beta$-endorphin : $\beta$-LPH $=27 \pm 6 ; 1$ ). These data are in agreement with all of our previous data on normal rats demonstrating a large amount of $\beta$-endorphin size material in plasma, a substantial portion of which is derived from intermediate lobe melanotropes. Despite similar plasma concentrations of $\beta$-endorphin-IR between $12 \mathrm{~h}$ sham $\mathrm{ADX}$ and $12 \mathrm{~h}$ ADX rats, there are already changes in the ratio of $\beta$-LPH to $\beta$-endorphin present in plasma (Fig. 1C). At $12 \mathrm{~h}$, the shams demonstrate a ratio of $\beta$-endorphin: $\beta$-LPH of $14: 1$, while the ADX animals demonstrate a ratio of $\beta$ endorphin to $\beta$-LPH of $3: 1$. At $24 \mathrm{~h}$, there is a still greater increase in $\beta$-LPH in the ADX rats so the ratio of $\beta$-endorphin : $\beta$ LPH is now $1.1: 1$. By 3 days the ratio of $\beta$-endorphin: $\beta$-LPH drops to $0.7: 1$, indicating a predominance of $\beta$-LPH over $\beta$ endorphin at this time point. At this same time point, the pituitary content of $\beta$-endorphin has returned to normal (Fig. 1B). At day 5 , the ratio of $\beta$-endorphin : $\beta$-LPH has returned to $1: 1$. At day 10 the anterior pituitary content is now 3 -fold higher than sham ADX and the ratio of $\beta$-endorphin: $\beta$-LPH in plasma is $1.5: 1$. At all these time points, sham ADX show a mean ratio of $\beta$-endorphin : $\beta$-LPH of $27 \pm 6: 1$.

ADX is accompanied by a substantial degree of surgical stress as well as removal of glucocorticoid negative feedback. In an attempt to reduce the stress and focus on removal of negative feedback, studies with metyrapone were undertaken. Metyrapone acts to block the last step in corticosterone synthesis and results in the secretion of 11-deoxycorticosterone rather than corticosterone itself. A pilot study with metyrapone indicated no change in $\beta$-endorphin-IR concentrations at $24 \mathrm{~h}$ but increased plasma
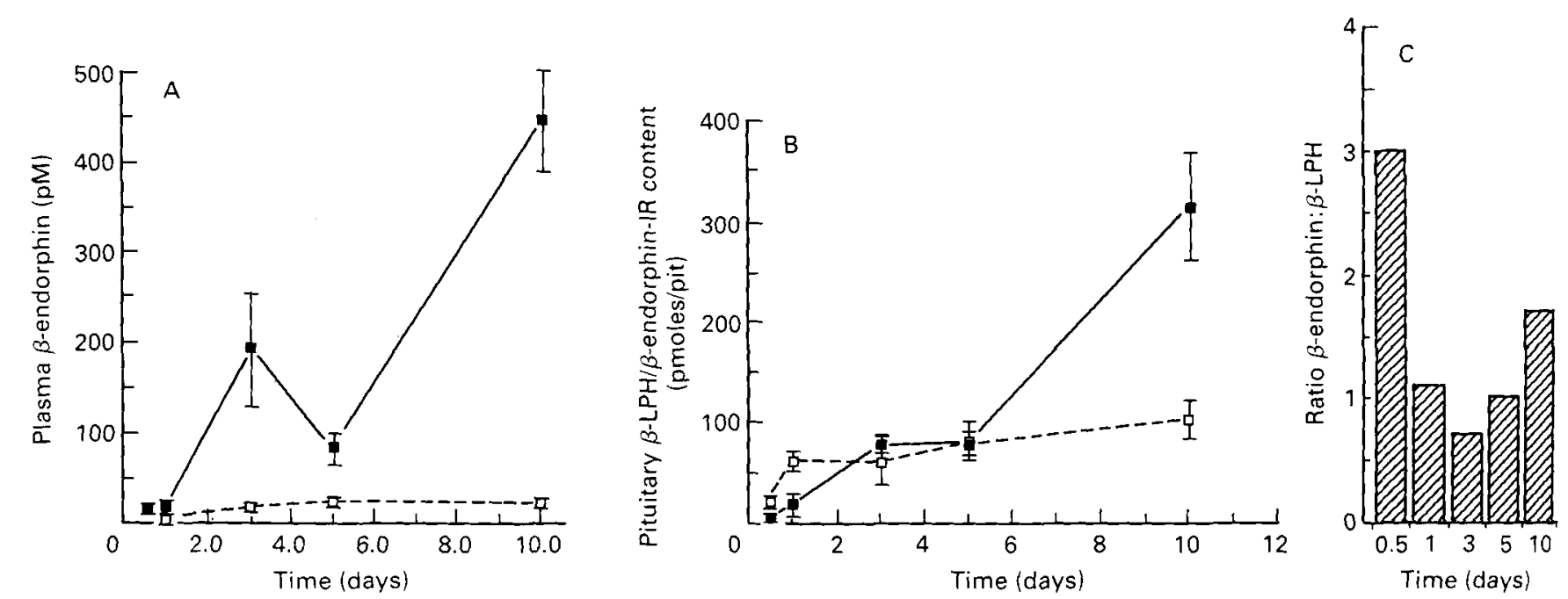

FIG. 1. Time course experiment of plasma and pituitary response to ADX. The $\beta$-endorphin release into plasma is shown in (A) ( $\square$, sham; $\mathbf{a}$, ADX). At 12 and $24 \mathrm{~h}$, plasma $\beta$-endorphin-IR concentrations are indistinguishable from shams. By day 3 , there is increased secretion that persists through day 10. (B) The pituitary content demonstrates depletion of $\beta$-endorphin stores at 12 and $24 \mathrm{~h}$, with a return to normal by day 3 . At day 10 , the total peptide stores are elevated 3-fold over shams ( $\square$, sham; $\mathbf{D}$, ADX). (C) The ratio of $\beta$-endorphin: $\beta$-LPH in plasma following ADX as determined by molecular sieving. Although initial release at $12 \mathrm{~h}$ demonstrates more $\beta$-endorphin than $\beta$-LPH, on days 1,3 and 5 , the proportions of $\beta$-endorphin and $\beta$-LPH are approximately equal. By day $10, \beta$-endorphin begins to predominate again. 
concentrations at $72 \mathrm{~h}$ (Fig. 2). A repeat experiment examined the effect of metyrapone on the ratio of $\beta$-endorphin: $\beta$-LPH. The number of rats per group varied from 11 to 15 , and is indicated in parenthesis in Table 1. In neither of the studies examining $24 \mathrm{~h}$ metyrapone treatment is the plasma level of $\beta$ endorphin-IR increased in comparison to DMSO-treated animals. In both studies the $\beta$-endorphin-IR was significantly increased at $72 \mathrm{~h}$ in comparison to DMSO-injected control (two-way ANOVA: experiment 1 , metyrapone $\times$ day interaction, $F=6.3$, $\mathrm{df}=1, \mathrm{P}=0.018$; experiment 2 , metyrapone $\times$ day interaction, $\mathrm{F}=25.97, \mathrm{df}=1, \mathrm{P}=0.0001$ ). In neither of these studies is there a significant effect of metyrapone on $\beta$ - LPH $/ \beta$-endorphin anterior pituitary content at 24 or $72 \mathrm{~h}$ (Table 1 ). Studies currently in progress suggest there is an early rise in plasma $\beta$-endorphin-IR observable at $4 \mathrm{~h}$ but by $24 \mathrm{~h}$ plasma concentrations are back to normal.

The plasma sieving data from metyrapone-treated animals are similar to the ADX group. The ratio of $\beta$-endorphin: $\beta$-LPH in plasma of $24 \mathrm{~h}$ DMSO-treated animals is 12.1 , while the mean ratio of $\beta$-endorphin: $\beta$-LPH in plasma from $24 \mathrm{~h}$ metyraponetreated animals is $1.5: 1$, an 8 -fold difference in the ratio. Again, similar to the $12 \mathrm{~h} \mathrm{ADX}$ data, this shift occurs despite the same plasma concentrations of total $\beta$-endorphin-IR. There is also little difference in the ratio of $\beta$-endorphin: $\beta$-LPH between the

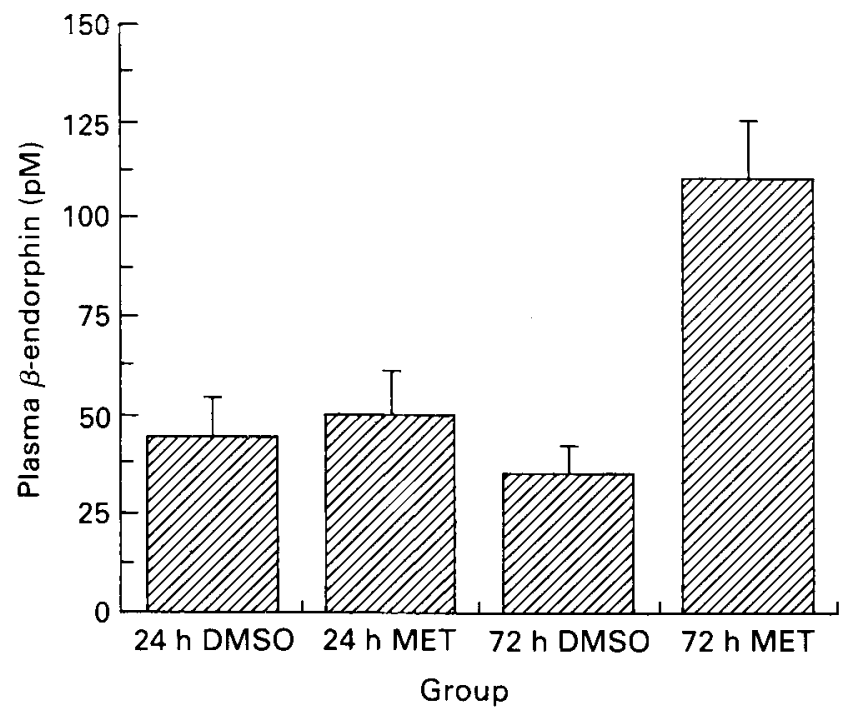

FIG. 2. Plasma $\beta$-endorphin-IR response to metyrapone (MET) treatment for 24 and $72 \mathrm{~h}$. No change in plasma $\beta$-endorphin-IR was seen at $24 \mathrm{~h}$, but there was a significant increase in plasma $\beta$-endorphin-IR at $72 \mathrm{~h}$.
24 and $72 \mathrm{~h}$ metyrapone-treated rats, despite elevated plasma concentrations of $\beta$-endorphin-IR at $72 \mathrm{~h}$. In both the 24 and $72 \mathrm{~h}$ metyrapone-treated groups, $\beta$-endorphin size material is the predominant form in plasma. A repeat study examined the $24 \mathrm{~h}$ time point, and anterior pituitaries were tested for their in vitro response to $\mathrm{CRH}$. In this study, plasma $\beta$ - $\mathrm{LPH} / \beta$-endorphin concentrations were again similar between groups. $($ DMSO $=$ $72 \pm 9$, metyrapone $=58 \pm 9 ; n=6,7$ per group). Plasma sieving demonstrated a 9 -fold shift in the ratio of $\beta$-endorphin: $\beta$-LPH to favor more $\beta$-LPH as seen in the previous studies.

\section{Response of anterior pituitary in vitro}

To confirm that changes in plasma ratios of $\beta$-endorphin: $\beta$ LPH were due to shifts in anterior lobe corticotrope release, anterior pituitary cell suspensions from control and treated rats were tested in vitro with oCRH. Both unhandled control rats and DMSO-treated rats were included as control groups. The pituitaries from 6 rats per group were pooled. Following dispersion of anterior pituitary cells into single cell preparations, aliquots of cells were stimulated for $1 \mathrm{~h}$ with oCRH. The media from the dispersed anterior pituitary cells stimulated with oCRH were assayed for total $\beta$-endorphin-IR then applied to a G-50 sieving column. All pituitary cell preparations demonstrated an increased release of $\beta$-endorphin-IR with $\mathrm{CRH}$ stimulation (Fig. 3A). The sieving data are shown in (Fig. 3B). The baseline (unstimulated secretion) from unhandled control pituitary cells show 1.5 -fold more $\beta$-LPH than $\beta$-endorphin; the pituitary cells from DMSO-treated rats demonstrate equal parts of $\beta$-LPH and $\beta$-endorphin secreted into the media. These are in agreement with our pilot as well as previous studies (2) demonstrating approximately equal parts of $\beta$-LPH and $\beta$-endorphin or a predominance of $\beta$-LPH in unstimulated release from anterior pituitaries from normal rats. In contrast, the pituitaries from metyrapone-treated rats show 2-fold more $\beta$-endorphin than $\beta$ LPH secretion at baseline (unstimulated secretion). Following stimulation with oCRH, the ratio of $\beta$-endorphin to $\beta$-LPH released (total minus unstimulated) changes for the various groups (Fig. 3). The unhandled control and DMSO-treated groups demonstrate a mean ratio of $\beta$-endorphin: $\beta$-LPH of $2.0 \pm 0.1: 1$. The pituitaries from metyrapone-treated animals demonstrate a ratio of $1.1: 1$. These data are consistent with in vivo plasma data suggesting that chronic drive leads to proportionately more $\beta$-LPH in the releasable pool. The differences in forms released in these short-term suspensions are not due to differences in the ratio of $\beta$-LPH and $\beta$-endorphin in the total stores (Table 2). Both DMSO-treated and metyrapone-treated

TABLE 1. Effect of Metyrapone Treatment on Plasma $\beta$-Endorphin, Ratio of $\beta$ Endorphin to $\beta$-LPH in Plasma and Anterior Pituitary $\beta$-Endorphin $/ \beta$-LPH Content.

$\begin{array}{lll}\text { Plasma } \beta \text {-endorphin-IR } & \begin{array}{l}\text { Plasma ratio } \\ \beta \text {-endorphin: } \beta \text {-LPH }\end{array} & \begin{array}{l}\text { Anterior pituitary } \\ \beta \text {-endorphin-IR } \\ \text { content }(p m o l e s / p i t) \\ (x \pm S E M)\end{array} \\ & & \end{array}$

\begin{tabular}{lccr}
\hline 24 h DMSO (11) & $85 \pm 9$ & $12: 1$ & $98 \pm 26$ \\
24 h Metyrapone (12) & $68 \pm 20$ & $1.5: 1$ & $92 \pm 34$ \\
72 h DMSO (15) & $73 \pm 14$ & $6: 1$ & $139 \pm 26$ \\
72 h Metyrapone (15) & $247 \pm 31$ & $1.2: 1$ & $130 \pm 26$ \\
\hline
\end{tabular}

The number of rats per group is indicated in parenthesis. 

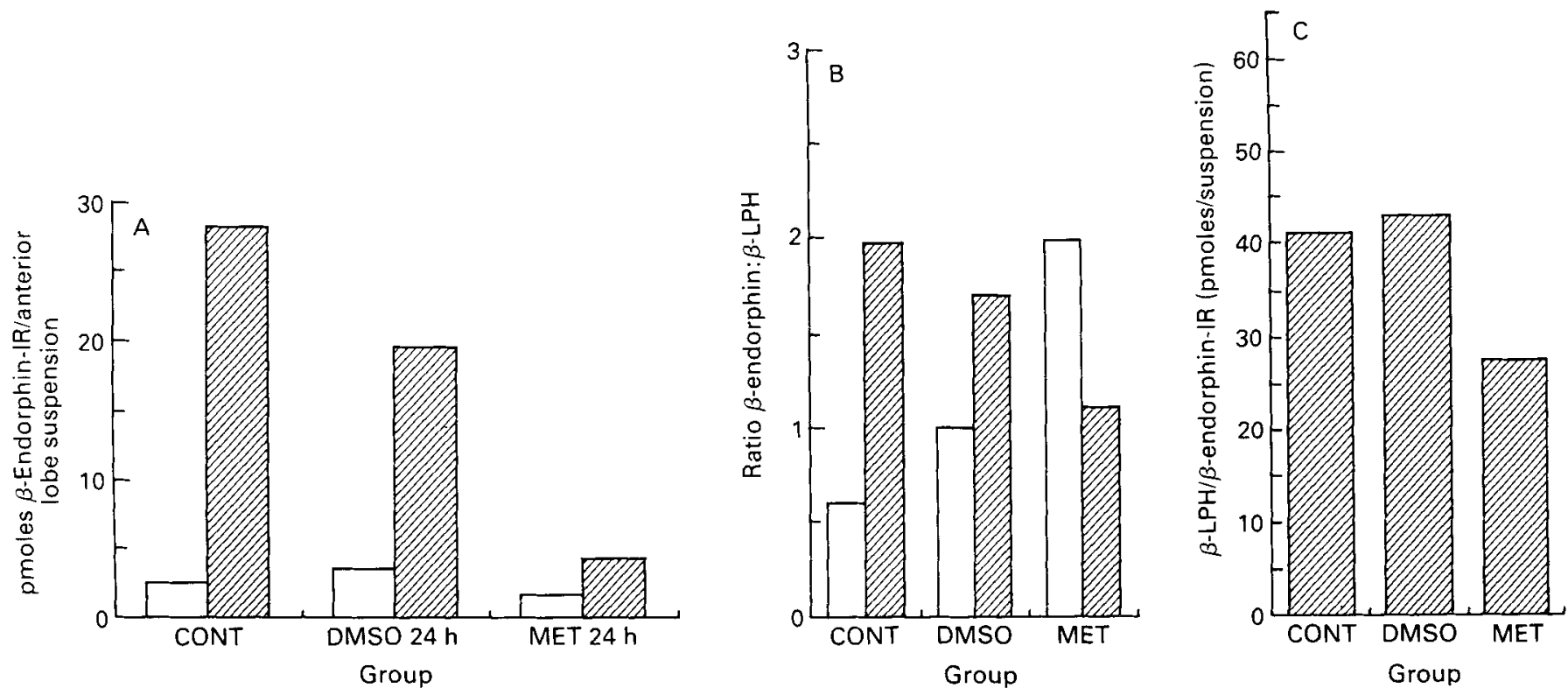

FIG. 3. Pituitary $\beta$-endorphin response to oCRH in metyrapone (MET)-treated rats tested in vitro. The response to oCRH is small in pituitaries from rats given metyrapone for $24 \mathrm{~h}$ (A). Likewise, the stores of $\beta$-endorphin may be depleted (C). The proportion of $\beta$-endorphin to $\beta$-LPH secreted into media at baseline and in response to oCRH stimulation, as determined by molecular sieving, is shown in (B). Both unhandled control (CONT) and vehicle-treated control (DMSO) demonstrate predominantly $\beta$-LPH at baseline, and 2 -fold more $\beta$-endorphin than $\beta$-LPH following stimulation. In contrast, metyrapone-treated rats demonstrate more $\beta$-endorphin at baseline, with a shift towards more $\beta$-LPH following oCRH stimulation. (A and в): $\square$, unstimulated:

Table 2. Effect of Metyrapone Treatment on Ratio $\beta$ Endorphin: $\beta$-LPH Released by oCRH and Ratio $\beta$ Endorphin: $\beta$-LPH in Anterior Pituitary Stores.

\begin{tabular}{|c|c|c|c|}
\hline & $\beta-L P H$ & $\beta$-Endorphin & Ratio $\beta$-endorphin : $\beta$-LPH \\
\hline \multicolumn{4}{|c|}{ A. Anterior lobe suspensions media $=\beta$-endorphin-IR released } \\
\hline Control & 177 & 367 & $2,1: 1$ \\
\hline DMSO & 311 & 593 & $1.9: 1$ \\
\hline Metyrapone & 118 & 136 & $1.1: 1$ \\
\hline \multicolumn{4}{|c|}{ B. Anterior lobe cells } \\
\hline Control & 538 & 421 & $0.8: 1$ \\
\hline DMSO & 389 & 207 & $0.5: 1$ \\
\hline Metyrapone & 298 & 156 & $0.5: 1$ \\
\hline
\end{tabular}

rats demonstrate similar ratios of $\beta$-endorphin: $\beta$-LPH in the anterior pituitaries $(0.5: 1)$ but release different proportions of $\beta$-endorphin : $\beta$-LPH in response to oCRH in vitro. A similar in vitro study was conducted with anterior pituitary cell suspensions from sham and $24 \mathrm{~h}$ ADX rats. The ADX rats demonstrate a greater ratio of $\beta$-endorphin: $\beta$-LPH in anterior pituitary cells than the sham ADX rats $(0.5: 1$ in sham; $0.8: 1$ in $\mathrm{ADX})$, but sham rats release proportionately more $\beta$-endorphin in response to $\mathrm{CRH}$ in vitro (ratio of $\beta$-endorphin: $\beta$-LPH $1.9: 1$ in sham and $1.2: 1$ in ADX).

Since both ADX and metyrapone treatments are accompanied by increases in both CRH and AVP secretion in vivo, the final experiment examined whether $\mathrm{CRH}$ and AVP may recruit different corticotrope populations that secrete different proportions of $\beta$-endorphin: $\beta$-LPH. Anterior pituitaries from normal rats were prepared into single cell preparations, then challenged with oCRH or AVP. Following $1 \mathrm{~h}$ of challenge, the media were collected and sieved. The basal unstimulated release demonstrated equal proportions of $\beta$-LPH and $\beta$-endorphin released into the media. Both oCRH and AVP stimulated 2-fold more $\beta$-endorphin than $\beta$-LPH.

\section{Discussion}

These data support in vitro data suggesting that increased secretory drive results in a shift in the ratio of $\beta$-endorphin: $\beta$ LPH released from the anterior pituitary. The ADX data provide the strongest in vivo support for this hypothesis. At $12 \mathrm{~h}$ following $\mathrm{ADX}$, there is 3 -fold more $\beta$-endorphin than $\beta$-LPH in plasma. By $24 \mathrm{~h}$ following $\mathrm{ADX}$, the ratio of $\beta$-endorphin: $\beta$-LPH in plasma has dropped to $1.1: 1$, although the plasma concentrations of $\beta$-endorphin-IR are not elevated at this time. Since the conditions of the $\beta$-endorphin RIA strongly prefer carboxyterminal intact $\beta$-endorphin over the carboxyterminal shortened forms released from intermediate lobe, these data suggest that the anterior lobe contributes to the $\beta$-endorphin pool in control rats, and that the changes seen in the ratios of $\beta$-endorphin: $\beta$-LPH following ADX represent changes in anterior lobe secretion. The ADX data are further supported by the $24 \mathrm{~h}$ metyrapone treatment data, where plasma concentrations of $\beta$-endorphin-IR are unchanged by metyrapone treatment but there is an $8-$ to 9 -fold shift in the ratio of $\beta$-endorphin : $\beta$-LPH to favor $\beta$-LPH secretion. In the ADX time course experiment, approximately equal parts of $\beta$-LPH and $\beta$-endorphin are present in plasma until the 10 day point when $\beta$-endorphin again predominates. The increased proportion of $\beta$-LPH in plasma at early time points could be secondary to the longer half-life of $\beta$-LPH in comparison to $\beta$-endorphin. However, a longer half-life of $\beta$ LPH is not the sole reason for these changes in ratio of $\beta$ endorphin: $\beta$-LPH since there appears to be an increase in this 
ratio at later time points in the ADX rats, when plasma secretion and concentration of $\beta$-endorphin-IR are greatly elevated in ADX rats. Particularly at 10 days, the time point when plasma $\beta$-endorphin-IR concentrations are the highest following ADX, the ratio of $\beta$-endorphin: $\beta$-LPH has returned to $1.7: 1$. A previous study also demonstrated a shift in the ratio of $\beta$-LPH to $\beta$-endorphin secreted into plasma to favor more $\beta$-endorphin in 14 day ADX as compared to 7 day ADX rats (16).

While both metyrapone and $\mathrm{ADX}$ result in removal of glucocorticoid negative feedback, metyrapone treatment results in only a partial blockade of glucocorticoids, with approximately $40 \%$ to $50 \%$ block in authentic corticosterone production (17). Consequently, ADX versus metyrapone-treated groups differ in concentrations of circulating glucocorticoids. However, both treatments do result in increased secretion, and both treatments result in a shift in the ratio of $\beta$-endorphin: $\beta$-LPH in plasma, even at the $24 \mathrm{~h}$ time point when there is no change in circulating plasma concentrations between the treated groups and their respective controls. In part, this may result from significant early release in both ADX and metyrapone-treated rats, which resulted in a relative depletion of $\beta$-endorphin in the releasable pool. The in vitro data further demonstrate that anterior pituitaries from control or DMSO-treated rats release approximately 2-fold more $\beta$-endorphin than $\beta$-LPH with oCRH challenge, while anterior pituitaries from metyrapone-treated rats demonstrate a $1: 1$ ratio of $\beta$-endorphin : $\beta$-LPH following oCRH challenge. This difference in release is not accounted for by changes in the ratio of $\beta$ endorphin: $\beta$-LPH present in the anterior pituitaries; both DMSO- and metyrapone-treated rat pituitaries demonstrate ratios of $\beta$-endorphin: $\beta$-LPH of $0.5: 1$, but release different proportions of $\beta$-endorphin: $\beta$-LPH following oCRH challenge. These in vitro data are in agreement with in vitro data of Ham and Smyth $(9,10)$ suggesting that brief exposure of anterior pituitary primary cell cultures to oCRH resulted in primarily $\beta$ endorphin release, but chronic exposure to oCRH shifted the release to predominantly $\beta$-LPH.

In conclusion, these data provide strong support for the hypothesis that chronic $\mathrm{CRH}$ drive leads to changes that alter the mixture of products in secretory granules of anterior lobe corticotropes. These changes are difficult to predict based upon molar ratio of precursor and products present in the corticotrope cells. In part, this may result from the inclusion of a number of immature and newly synthesized granules not present in the readily releasable pool in quantitation of $\beta$-LPH and $\beta$-endorphin stores. This suggests that the initial processing step yielding $\beta$ $\mathrm{LPH}$ and the $22 \mathrm{~K}$ ACTH intermediate is quite rapid, while the processing of $\beta$-LPH to $\beta$-endorphin is rate limiting in times of chronic drive. This processing enzyme may be inducible at later time points as suggested by 10 day ADX data. These changes in the mixture of secretory products in the releasable pool can lead to changes in the messages delivered to target organs in situations of chronic demand.

\section{Materials and Methods}

\section{Treatments}

Male Sprague-Dawley rats (175 to $250 \mathrm{~g}$ ) obtained from Charles River (Portage, MI, USA) were maintained in a controlled environment on a $12 \mathrm{~h} \mathrm{light/dark} \mathrm{schedule.} \mathrm{Animals} \mathrm{were} \mathrm{given} 5$ to 7 days to adapt to the new environment before the initiation of treatments. ADX were done with a dorsal surgical approach under chloral hydrate anesthesia. ADX animals were given $0.9 \% \mathrm{NaCl}$ in their drinking water following the surgery. The completeness of ADX was verified by measurement of plasma corticosterone in blood obtained at the time of sacrifice.

Metyrapone was obtained from Sigma (St. Louis, MO, USA). It was dissolved in DMSO and administered $200 \mathrm{mg} / \mathrm{kg}$ subcutaneously every $8 \mathrm{~h}$. A final injection was given 30 to $60 \mathrm{~min}$ before sacrifice. Control animals received DMSO injections at the same time points. In some cases an unhandled control group is included as a further control for the stress of injection. Animals were sacrificed by decapitation and trunk blood was collected in $\mathrm{K}^{+}$EDTA tubes for hormonal measurements. Metyrapone- and DMSO-treated rats were sacrificed at $1700 \mathrm{~h}$, at the peak of circadian drive, except in the final experiment involving in vitro testing of anterior pituitaries. In all studies, pituitaries were dissected into anterior and neurointermediate lobes and the portion of the anterior lobe underlying the neurointermediate lobe was discarded. This prevents contamination of the anterior pituitary fragments with intermediate lobe melanotropes. At the time of sacrifice, anterior pituitary fragments were frozen on dry ice for measurement of content or placed in Krebs-Ringer bicarbonate buffer until further processing for short-term anterior lobe suspensions.

\section{Tissue processing}

Plasma was extracted with Sep-Pak $C_{18}$ cartridges for $\beta$-endorphin-IR measurements as previously described (17). An aliquot of this eluate was used for corticosterone measurement. Anterior pituitaries were extracted with LET (lithium, EDTA, tris) extraction medium to permit quantitation of mRNA and RIA on the same sample. An aliquot equal to $1 / 30$ of the anterior pituitary was taken for peptide measurement before the addition of proteinase $\mathbf{K}$. This peptide aliquot was diluted in an acid: acetone extraction medium $(3: 1$ mixture acetone: $0.2 \mathrm{~N} \mathrm{HCl})$ and centrifuged. The supernatant was saved then lyophilized prior to RIA. Studies in our laboratory have validated similar recovery of $\beta$-endorphin-IR with LET extraction and the acid: acetone extraction method that we have used previously.

Anterior lobes used for in vitro response to oCRH and AVP were processed as previously described (18). Briefly, the anterior pituitaries were treated with collagenase for $60 \mathrm{~min}(3 \mathrm{mg} / \mathrm{ml}$; Sigma) to obtain a single cell preparation, filtered through $50 \mu \mathrm{m}$ nylon mesh to remove fibrin and clumps, then washed in Krebs to remove collagenase. The cells were preincubated for $90 \mathrm{~min}$ in Krebs under $95 \% \mathrm{O}_{2} / 5 \% \mathrm{CO}_{2}$ to stabilize the suspensions. After preincubation, the cells were centrifuged $(100 \times \mathrm{g})$ and fresh medium containing desired secretagogs was added to aliquots of the cell suspension. All concentrations of secretagogs were run in triplicate, and the medium from the triplicates pooled for extraction and hormonal measurement. Baseline secretion was assessed in two separate aliquots of the cell suspensions. Secretagogs oCRH and AVP were added in $1 \mathrm{nM}$ and $10 \mathrm{nM}$ concentrations, respectively. The incubations were conducted at $37^{\circ} \mathrm{C}$ in a water bath under $95 \% \mathrm{O}_{2} / 5 \% \mathrm{CO}_{2}$. Following $60 \mathrm{~min}$, these cells were centrifuged and the media saved for extraction with Sep-Pak $\mathrm{C}_{18}$ cartridges using the same extraction as plasma. The cells were lysed by freezing and thawing in $5 \mathrm{~N}$ acetic acid with $0.5 \%$ bovine serum albumin (Sigma). Following centrifugation, the supernatant was removed and lyophilized for future RIA.

\section{Hormonal assays}

The $\beta$-endorphin assay utilized an antibody raised against $\beta$-endorphin $_{1-31}$ human sequence $\left[\beta\right.$-endorphin $\left.{ }_{1-31 / h}\right]$ used at a final dilution of $1 / 40,000$. This is primarily a midportion antibody that shows $100 \%$ crossreactivity with $\beta$-LPH and POMC under the condition of this assay. $\left[{ }^{125} \mathrm{I}\right] \beta$-endorphin ${ }_{1-31(\mathbf{h})}$ was used as the standard. The samples and standards were dissolved in $0.1 \%$ human serum albumin (Fraction V; Sigma) which was acidified to $\mathrm{pH} 3.0$ with $1 \mathrm{~N} \mathrm{HCl}$. Samples from each rat were assayed prior to pooling for molecular sieving of $\beta$-endorphinIR. Under the conditions of the assay, this antibody showed $50 \%$ to $85 \%$ cross-reactivity with various $\mathrm{N}$-terminal acetylated forms of $\beta$ endorphin-IR.

Aliquots of Sep-Pak extracted plasma were taken for corticosterone assay and were lyophilized, then extracted in ethanol saline and assayed using a competitive protein binding assay as previously described (18). $\left[{ }^{3} \mathrm{H}\right]$ Corticosterone was used as the label and unlabelled corticosterone as the standard. This assay measures all steroids and is not useful for studies with metyrapone-treated animals since 11-deoxycorticosterone is 
$120 \beta$-Endorphin/ $\beta$-lipotropin release with diminished glucocorticoid secretion

fully capable of displacing corticosterone in the competitive protein binding assay.

\section{Gel filtration}

To determine the molecular forms of $\beta$-endorphin-IR present in plasma, media and cell extracts, samples from rats from the same treatment groups were pooled and applied to a $90 \times 1.5 \mathrm{~cm}$ G-50 molecular sieving column. The column was developed in $1 \%$ formic acid. Fractions of $2.2 \mathrm{ml}$ size were collected. The fractions were lyophilized, then resuspended in $0.1 \%$ HSA as previously described for RIA.

\section{Acknowledgements}

The authors would like to acknowledge the support of MH 42251 to S.J.W. and H.A. and MH 00427 and MH 45232 to E.A.Y.

\section{Accepted 15 October 1992}

\section{References}

1. Eipper B, Mains R. (1978). Existence of a common precursor to ACTH and endorphin in the anterior and intermediate lobes of the rat pituitary. J Supram Struc. 8: 247-262.

2. Eipper BA, Mains RE. (1980). Structure and biosynthesis of proadrenocorticotropin/endorphin and related peptides. Endocr Rev. 1: 1-27.

3. Young EA, Lewis J, Akil H. (1986). The preferential release of betaendorphin from the anterior pituitary lobe by corticotropin releasing factor (CRF). Peptides. 7: 603-607.

4. Watson SJ, Lopez JF, Young EA, Vale W, Rivier J, Akil H. (1988). Effects of low dose oCRH in humans: endocrine relationships and $\beta$ endorphin/ $\beta$-lipotropin responses. J Clin Endocrinol Metab. 66: 10-15.

5. Young EA, Grunhaus L, Haskett RF, Pande AC, Murphy-Weinberg V, Watson SJ, Akil H. (1991). Heterogeneity in the $\beta$-endorphin response to electroconvulsive therapy. Arch Gen Psychiatry. 48: 534-539.

6. Vale W, Vaughan J, Smith M, Yamamoto G, Rivier J, Rivier C. (1983). Effects of synthetic ovine CRH, glucocorticoids, catecholamines, neurohypophysial peptides and other substances on cultured corticotropic cells. Endocrinology. 113: 1121.

7. Vale W, Rivier J, Guillemin R, Rivier C. (1979). Effects of purified
$\mathrm{CRH}$ and other substances on secretion of ACTH and $\beta$-endorphinlike immunoactivities by cultured anterior or neurointermediate pituitary cells. In: Collu R, ed. CNS effects of hypothalamic hormones and other peptides, 163. Raven Press, New York.

8. Wand GS, May V, Eipper BA. (1988). Comparison of acute and chronic secretagogue regulation of proadrenocorticotropin/endorphin synthesis, secretion and messenger ribonucleic acid production in primary cultures of rat anterior pituitary. Endocrinology. 123: 11531161.

9. Ham J, Smyth DJ. (1985). $\beta$-Endorphin and ACTH related peptides in primary cultures of rat anterior pituitary cells: evidence for different intracellular pools. FEBS Lett. 190: 253.

10. Ham J, Smyth DJ. (1986). Chronic stimulation of anterior pituitary cell cultures with $\mathrm{CRH}$ leads to the secretion of lipotropin. Neuroendocrinology. 44: 433.

11. Nakanishi S, Kita T, Taii S, Imura H, Numa S. (1977). Glucocorticoid effect on the level of corticotropin messenger RNA activity in rat pituitary. Proc Natl Acad Sci USA. 74: 3283.

12. Roberts JL, Budarf MJ, Baxter JD, Herbert E. (1979). Selective reduction of proadrenocorticotropin/endorphin protein and messenger ribonucleic acid activity in mouse pituitary tumor cells by glucocorticoids. Biochemistry. 18: 4907

13. Birnberg NC, Lissitzky JC, Hinman M, Herbert E. (1983). Glucocorticoids regulate proopiomelanocortion gene expression in vivo at the levels of transcription and secretion. Proc Natl Acad Sci USA. 808: 6982-6986.

14. Sawchenko PE, Swanson LW, Vale WW. (1984). Coexpression of corticotropin-releasing factor and vasopressin immunoreactivity in parvocellular neurosecretory neurons of the adrenalectomized rat. Proc Natl Acad Sci USA. 81: 1883-1887.

15. Plotsky PM, Sawchenko PE. (1987). Hypophysial-portal plasma levels, median eminence content, and immunohistochemical staining of corticotropin-releasing factor, arginine vasopressin, and oxytocin after pharmacological adrenalectomy. Endocrinology. 120: 1361-1369.

16. Young EA. (1989). Adrenalectomy increases $\beta$-lipotropin secretion over $\beta$-endorphin secretion from anterior pituitary corticotrophs. Life Sci. 45: 2233-2237.

17. Cahill C, Matthews JC, Akil H. (1983). Human plasma $\beta$-endorphinlike peptides: a rapid high recovery extraction technique and validation of the immunoassay. J Clin Endocrinol Metab. 56: 992.

18. Young EA, Akil H. (1985). Corticotropin-releasing factor stimulation of adrenocorticotropin and beta-endorphin release: effects of acute and chronic stress. Endocrinology. 117: 23-30. 